\title{
A Critical Period for Nicotine-Induced Disruption of Synaptic Development in Rat Auditory Cortex
}

\author{
V. Bess Aramakis, ${ }^{1}$ Candace Y. Hsieh, ${ }^{1}$ Frances M. Leslie, ${ }^{2}$ and Raju Metherate ${ }^{1}$ \\ Departments of ${ }^{1}$ Neurobiology and Behavior and ${ }^{2}$ Pharmacology, University of California, Irvine, \\ California 92697-4550
}

\begin{abstract}
Cholinergic markers in the middle layers of rat auditory cortex are transiently upregulated during the second postnatal week, at which time $\alpha 7$ nicotinic acetylcholine receptors (nAChRs) selectively regulate NMDA receptor (NMDAR)-mediated EPSPs. To investigate the developmental role of this regulation, we determined whether manipulating $\mathrm{nAChR}$ function at specific times during the first 4 weeks after birth could alter subsequent neuronal function. Rat pups were injected twice daily with nicotine (1 or $2 \mathrm{mg} / \mathrm{kg}$ ) or saline during approximately the first, second, or fourth postnatal week (i.e., before, during, or after the peak upregulation of nAChRs). Glutamate EPSPs and intrinsic membrane properties were measured during whole-cell recordings from visually identified pyramidal neurons in layers II-IV of brain slices prepared at least $15 \mathrm{hr}$ after the last injection. Chronic nicotine exposure (CNE) had little effect on intrinsic membrane
\end{abstract}

properties and during week 1 or 4 did not affect synaptic function. However, CNE during week 2 resulted in EPSPs with long durations, multiple peaks, and enhanced NMDAR components. These changes remained significant even $10 \mathrm{~d}$ after CNE. Rapid application of nicotine, which in control neurons selectively enhances NMDAR EPSPs during week 2, produced only weak effects after CNE. Receptor binding studies showed that CNEinduced EPSP alterations occurred in the absence of altered $\alpha 7$ nAChR numbers or agonist binding affinity. Thus, altered stimulation of nAChRs by CNE during week 2, but not before or after, disrupts the development of glutamate synapses in rat auditory cortex.

Key words: acetylcholine; auditory; cortex; development; EPSP; glutamate; nicotine; NMDA; intrinsic properties; synaptic
Nicotine, the neuroactive ingredient in tobacco, is a highly addictive substance that has multiple effects on the nervous system (for review, see Benowitz, 1996; Dani and Heinemann, 1996; Role and Berg, 1996). The effects of nicotine extend to nonsmokers by way of secondhand smoke exposure, and both infants and fetuses are particularly vulnerable. Children born to mothers who smoked during pregnancy are often born prematurely and exhibit decreased body weight and size, increased body tremor, and impaired respiratory function (for review, see Nash, 1988). Perinatal nicotine exposure may also produce sensory deficits. For example, infants exposed to nicotine either in utero or after birth show decreased ability to habituate to sounds and to orient toward an auditory stimulus (Saxton, 1978; Picone et al., 1982) and continue to show auditory and auditory-related cognitive impairments as they mature (Sexton et al., 1990; McCartney et al., 1994; Fried et al., 1997). Thus, early exposure to nicotine can adversely affect nervous system development, including that of the auditory system.

During the second postnatal week in rats, primary sensory cortex displays a dramatic increase in expression of the cholinergic hydrolytic enzyme, acetylcholinesterase (AChE) (Kristt, 1979; Prusky et al., 1988; Robertson et al., 1991), and $\alpha 7$ nicotinic acetylcholine receptors (nAChRs) (Fuchs, 1989; Broide et al., 1995, 1996) in the middle cortical layers. This period corresponds to the third trimester of human development, when thalamic fibers innervate auditory neocortex and columns of AChE appear transiently in its middle layers (Krmpotic-Nemanic et al., 1980, 1983). Recently, we demonstrated that during the period of enhanced cholinergic expression in rat auditory cortex, rapid application of nicotine to pyrami-

Received March 28, 2000; revised May 22, 2000; accepted June 2, 2000.

This work was supported by the National Institute on Deafness and Other Communication Disorders (DC02967), the University of California Tobacco-Related Disease Research Program (8RT-0059), and the University of California Irvine Council on Research, Computing, and Library Resources. We thank Dr. Heather Oliff for participating in initial experiments, and Yiling Chen and Michelle Cheng for technical assistance.

Correspondence should be addressed to Dr. Raju Metherate, Department of Neurobiology and Behavior, University of California, Irvine, 2205 Biological Sciences II, Irvine, CA 92697-4550. E-mail: rmethera@uci.edu.

Copyright (C) 2000 Society for Neuroscience $0270-6474 / 00 / 206106-11 \$ 15.00 / 0$ dal neurons selectively enhances the NMDAR component of glutamate EPSPs (Aramakis and Metherate, 1998). This effect is most prominent during postnatal days (P) 8-12 ( $>80 \%$ of neurons affected) and virtually disappears after P19 ( $<6 \%$ of neurons). These findings suggest that $n A C h R$ regulation of NMDAR activity during the second postnatal week in the rat may be important for auditory cortex development.

The goal of this study was to determine whether manipulation of nAChRs via chronic nicotine exposure (CNE) could affect the functional development of auditory cortex. We report that $\mathrm{CNE}$ during the second postnatal week, but not during the first or fourth weeks, disrupts synaptic development by selectively altering NMDAR-mediated synaptic transmission. Thus, postnatal week 2 appears to be a sensitive period for the disruptive actions of nicotine that may lead to long-term impairment of auditory cortex function.

\section{MATERIALS AND METHODS}

CNE treatment. Pups from timed-pregnant Sprague Dawley rats (Charles River, Wilmington, MA) were maintained on a $12 \mathrm{hr}$ light/dark cycle. The date of birth was recorded as P0. Litters ranged in size from 10 to 16 pups, which were randomly assigned to saline or CNE treatment groups. Nicotine hydrogen tartrate was injected subcutaneously at a dose of either 1 or $2 \mathrm{mg} / \mathrm{kg}$ ( 0.35 or $0.7 \mathrm{mg} / \mathrm{kg}$ free base) in a $2 \mathrm{ml} / \mathrm{kg}$ volume using a 50 or $100 \mu \mathrm{l}$ Hamilton syringe. Saline-treated littermates received an equivalent volume of $0.9 \%$ sterile saline. Injections were made twice daily, at 8:00 9:00 A.M. and 4:00-5:00 P.M. After injections, pups were placed individually in an open container to monitor behavior for $2-15 \mathrm{~min}$ and then returned to their home cage and litter. Nicotine- and saline-treated pups gained weight at the same rate $(p>0.10)$.

Four CNE schedules (CNE groups I-IV) were used. These protocols were designed to expose pups at different developmental times relative to the $\alpha 7 \mathrm{nAChR}$ upregulation in cortical layer IV, which begins shortly after birth, peaks at $\sim$ P10, and ends after P15 (Broide et al., 1996). CNE group I pups were injected with nicotine $(2 \mathrm{mg} / \mathrm{kg})$ from P1 through P8-9 (treatments were maintained up to the day before electrophysiological recordings; slices were prepared the morning after the last injection). CNE group II rats were injected with either 1 or $2 \mathrm{mg} / \mathrm{kg}$ nicotine from P8 through P11-14, and slices were again prepared the next morning. CNE group III pups received $2 \mathrm{mg} / \mathrm{kg}$ nicotine from P8 through P16 and were allowed to survive an additional 7-10 d, and slices were made on P23 or P26. CNE group IV received $2 \mathrm{mg} / \mathrm{kg}$ nicotine from P20 through P23-25, and slices were prepared the morning after the last injection. 
A.

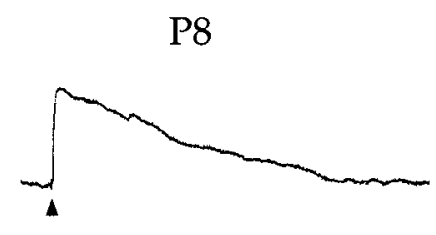

P13

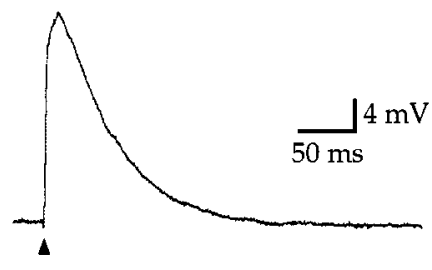

P20
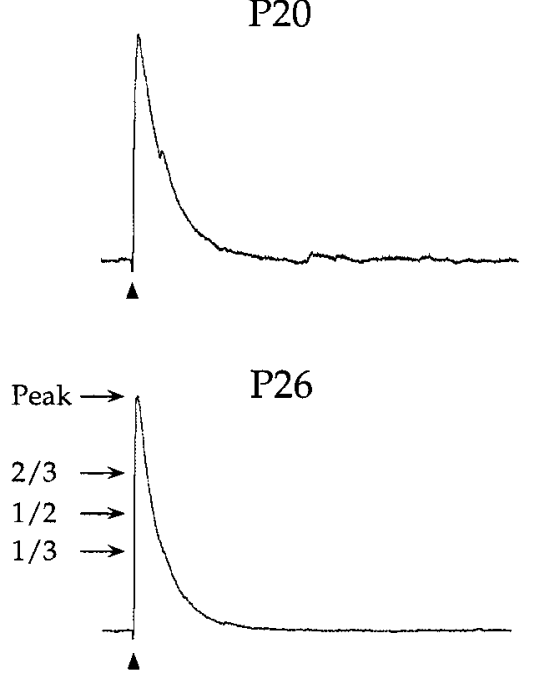

Bi.

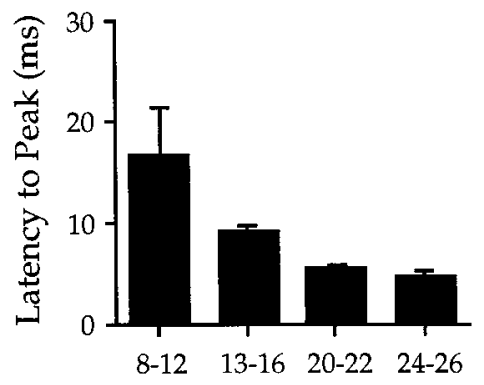

ii.

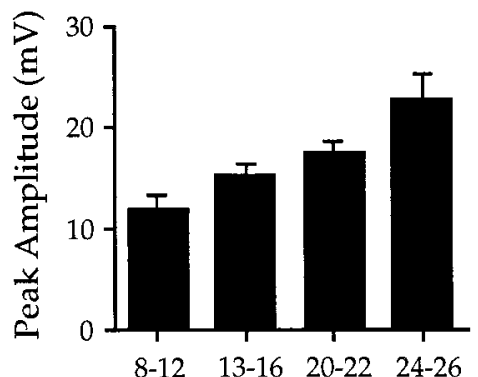

iii.

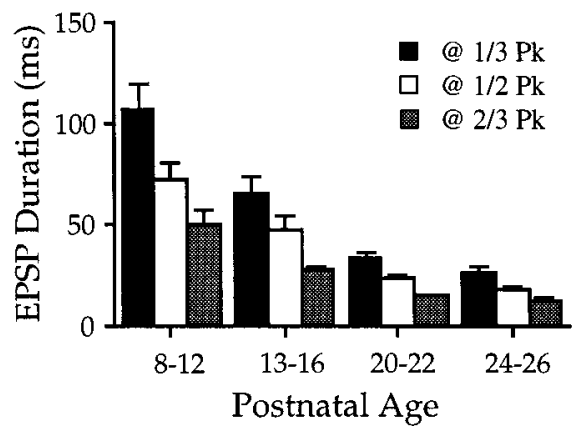

Figure 1. Normal development of EPSPs in pyramidal neurons of layers II-IV of auditory cortex. $A$, Maximal subthreshold EPSPs recorded in neurons from control P8-26 rats. $B$, Data on maximal subthreshold EPSPs grouped into four age ranges (values in Table 1). Bi, Latency to peak decreased over development. Bii, EPSP amplitude increased with age. Biii, EPSP duration, measured at 1/3, 1/2, and $2 / 3$ peak $(P K)(A$,arrows $)$, decreased with age.
The majority of experiments used a nicotine dose of $2 \mathrm{mg} / \mathrm{kg}(0.7 \mathrm{mg} / \mathrm{kg}$ free base, CNE groups I-IV). This dose is commonly used in CNE studies (Abdulla et al., 1996; Rowell and Li, 1997) to approximate blood levels of nicotine in smokers (Isaac and Rand, 1972; Murrin et al., 1987; Henningfield et al., 1993). Some animals in CNE group II received a lower dose of $1 \mathrm{mg} / \mathrm{kg}$ nicotine $(0.35 \mathrm{mg} / \mathrm{kg}$ free base).

Slice preparation and maintenance. Male and female rats $(8-26 \mathrm{~d}$ old $)$ were decapitated, and their brains were rapidly removed and placed in cold ACSF containing (in mM): $\mathrm{NaCl} 125.0, \mathrm{KCl} 2.5, \mathrm{NaHCO}_{3} 25.0, \mathrm{KH}_{2} \mathrm{PO}_{4}$ $1.25, \mathrm{MgSO}_{4} 1.2, \mathrm{CaCl}_{2} 2.0$, dextrose 10.0 , bubbled with $95 \% \mathrm{O}_{2}, 5 \% \mathrm{CO}_{2}$, pH 7.4 (osmolarity 298-302 mOsm/ $/ \mathrm{kg}$ ). Brains were blocked, and coronal sections $(300-400 \mu \mathrm{m})$ containing auditory cortex (Paxinos and Watson, 1986; Sally and Kelly, 1988) were made using a vibroslicer (WPI, Sarasota, FL). The location of auditory cortex was determined based on landmarks (e.g., the dorsoventral extent of the hippocampus and distance dorsal to the rhinal fissure) and comparison with previous results using AChE histochemistry, which delineates primary sensory cortex in juvenile rats (Robertson et al., 1991; Aramakis and Metherate, 1998). Layers II-IV were identified within the recording chamber by micrometer measurements of distance from the pia $(2.5 \mu \mathrm{m}$ resolution) and scaled to published values (Roger and Arnault, 1989). Slices were placed in a holding chamber containing oxygenated ACSF at room temperature. For recordings, a single slice was placed in a submersion recording chamber on the fixed stage of an upright microscope (Zeiss, Axioskop FS) and maintained at $34^{\circ} \mathrm{C}$ with an ACSF flow rate of $3.5-4.0 \mathrm{ml} / \mathrm{min}$.

Electrophysiological recording and stimulation. Neurons were visualized with infrared differential interference contrast (IR-DIC) optics with a video camera (Hamamatsu Photonics, Tokyo, Japan) and monitor (Stuart et al., 1993). Whole-cell recordings were made from the somas of layer II-IV neurons with clear ascending apical dendrites (i.e., presumed pyramidal neurons). Patch pipettes were made from filamented glass capillary tubes $(1.5 \mathrm{~mm}$ outer diameter, A-M Systems, Seattle, WA), with tip diameters of $\sim 2.5 \mu \mathrm{m}$ and DC resistances of 5-8 $\mathrm{M} \Omega$ using a horizontal micropipette puller (P-97, Sutter Instrument, Novato, CA). The pipettes were filled with (in mM): $125.0 \mathrm{~K}-\mathrm{MeSO}_{3}, 0.05 \mathrm{CaCl}_{2}, 0.5 \mathrm{NaCl}, 2 \mathrm{Mg}$-ATP,
$0.5 \mathrm{Na}-\mathrm{GTP}, 1.6 \mathrm{EGTA}$, and 10 HEPES. The $\mathrm{pH}$ was adjusted to 7.3 with $\mathrm{KOH}(1 \mathrm{M})$, and final osmolarity was $270-280 \mathrm{mOsm} / \mathrm{kg}$.

ACSF-filled micropipettes with tip diameters of $\sim 5 \mu \mathrm{m}$ were used for electrical stimulation of afferent fibers. The electrode was placed a distance of $50-125 \mu \mathrm{m}$ (mean $74 \pm 2 \mu \mathrm{m}, n=106$ ) lateral to the recording site, i.e., within the same cortical layer. Stimulation consisted of monophasic constant current pulses $(200 \mu \mathrm{sec}, 5-100 \mu \mathrm{A})$.

Recordings were obtained using an intracellular amplifier (Axoclamp 2B, Axon Instruments, Foster City, CA). Seal resistance was 5-12 G $\Omega$. Series resistance ranged from 3 to $25 \mathrm{M} \Omega$, but most often was $<12 \mathrm{M} \Omega$, and was compensated using the bridge balance. Membrane potential $\left(V_{\mathrm{m}}\right)$ was not corrected for liquid junction potential estimated to be approximately $-13 \mathrm{mV}$ (Metherate and Aramakis, 1999). $V_{\mathrm{m}}$ was monitored on an oscilloscope, digitized at $5.5 \mathrm{kHz}$, and stored on computer. Software (Axodata, Axograph, Axon Instruments) controlled data acquisition and analysis.

Pharmacological agents. Pharmacological agents included $( \pm)$-2-amino5-phosphonovaleric acid (APV; RBI, Natick, MA) and (-)-nicotine hydrogen tartrate (nicotine; Sigma, St. Louis, MO). APV was prepared as a concentrated stock solution in purified $\mathrm{H}_{2} \mathrm{O}$ and diluted to its final concentration with ACSF. Nicotine for subcutaneous injection was prepared weekly as a 0.5 or $1 \mathrm{mg} / \mathrm{ml}$ solution in $0.9 \%$ sterile saline, adjusted to $\mathrm{pH}$ 7.0-7.5 (1 M NaOH), and refrigerated. For rapid application to neurons in brain slices, nicotine was dissolved in ACSF $(25 \mu \mathrm{M})$ and applied by pressure ejection from a pipette with a $5 \mu \mathrm{m}$ tip, using a picospritzer (General Valve, Fairfield, NJ). The nicotine-filled pipette was placed within $30 \mu \mathrm{m}$ of the neuron's apical dendrite.

Electrophysiology analysis. For each cell, afferent stimulus intensities ranged from below the threshold for eliciting an EPSP to above the threshold for eliciting an action potential. For all ages and treatments, EPSP measurements were obtained using stimulus intensities that were just subthreshold for generating spikes ("maximum subthreshold EPSPs"). EPSP amplitude was measured at the absolute peak, and latency to peak was measured from stimulus onset. EPSP duration was measured at onethird, one-half, and two-thirds peak amplitude. Measurements were made 
Table 1. EPSPs in layers II-IV pyramidal neurons of rat auditory cortex during normal development and after CNE

\begin{tabular}{|c|c|c|c|c|c|c|c|}
\hline Age/condition & $\begin{array}{l}\text { Stimulus } \\
\text { intensity }(\mu \mathrm{A})\end{array}$ & $\begin{array}{l}\text { Latency to } \\
\text { peak }(\mathrm{msec})\end{array}$ & Peak $(\mathrm{mV})$ & $\begin{array}{l}\text { EPSP width@ } \\
\text { one-third peak }\end{array}$ & $\begin{array}{l}\text { EPSP width @ } \\
\text { one-half peak }\end{array}$ & $\begin{array}{l}\text { EPSP width @ } \\
\text { two-thirds peak }\end{array}$ & $n$ \\
\hline \multicolumn{8}{|l|}{ Development } \\
\hline P8-12 & $26.5 \pm 7.0$ & $16.8 \pm 4.7$ & $12.1 \pm 1.3$ & $107.8 \pm 12.3$ & $73.0 \pm 8.5$ & $50.6 \pm 6.6$ & 12 \\
\hline P13-16 & $22.7 \pm 3.6$ & $9.2 \pm 0.7$ & $15.3 \pm 1.2$ & $66.5 \pm 7.7$ & $48.3 \pm 6.9$ & $28.4 \pm 1.9$ & 17 \\
\hline P20-22 & $15.5 \pm 5.0$ & $5.7 \pm 0.4$ & $17.7 \pm 1.0$ & $34.5 \pm 1.8$ & $24.5 \pm 1.4$ & $16.4 \pm 1.1$ & 13 \\
\hline P24-26 & $12.4 \pm 3.5$ & $4.9 \pm 0.5$ & $23.0 \pm 2.5$ & $27.1 \pm 2.4$ & $18.3 \pm 2.2$ & $12.8 \pm 1.6$ & 5 \\
\hline Control & $38.8 \pm 12.4$ & $20.9 \pm 8.7$ & $11.0 \pm 1.7$ & $102.9 \pm 16.7$ & $72.7 \pm 14.6$ & $52.4 \pm 12.1$ & 6 \\
\hline CNE group I & $50.0 \pm 15.8$ & $20.0 \pm 5.5$ & $7.9 \pm 2.2$ & $115.5 \pm 14.7$ & $80.6 \pm 10.2$ & $53.6 \pm 6.7$ & 5 \\
\hline Control & $20.7 \pm 2.9$ & $10.2 \pm 1.2$ & $14.9 \pm 1.1$ & $76.3 \pm 8.6$ & $53.4 \pm 6.2$ & $32.8 \pm 2.9$ & 22 \\
\hline \multicolumn{8}{|l|}{ CNE group II } \\
\hline $1 \mathrm{mg} / \mathrm{kg}$ & $19.0 \pm 2.6$ & $14.5 \pm 2.9$ & $13.5 \pm 1.3$ & $112.3 \pm 11.8^{b}$ & $82.9 \pm 10.4^{b}$ & $61.9 \pm 8.9^{b}$ & 13 \\
\hline $2 \mathrm{mg} / \mathrm{kg}$ & $17.5 \pm 1.4$ & $17.5 \pm 4.1$ & $12.9 \pm 1.2$ & $118.5 \pm 14.9^{b}$ & $82.4 \pm 11.7^{b}$ & $60.8 \pm 10.0^{b}$ & 9 \\
\hline Control & $10.1 \pm 2.5$ & $4.7 \pm 0.3$ & $21.2 \pm 2.0$ & $27.3 \pm 1.9$ & $18.5 \pm 1.5$ & $12.7 \pm 1.1$ & 8 \\
\hline CNE group III & $9.5 \pm 1.8$ & $14.8 \pm 4.6$ & $16.3 \pm 2.0$ & $46.6 \pm 5.9^{b}$ & $36.6 \pm 5.5^{b}$ & $28.8 \pm 5.1^{b}$ & 7 \\
\hline Control & $10.1 \pm 2.5$ & $4.7 \pm 0.3$ & $21.2 \pm 2.0$ & $27.3 \pm 1.9$ & $18.5 \pm 1.5$ & $12.7 \pm 1.1$ & 8 \\
\hline CNE group IV & $12.1 \pm 2.6$ & $5.6 \pm 1.2$ & $20.3 \pm 1.6$ & $33.7 \pm 2.2$ & $24.3 \pm 2.4$ & $17.1 \pm 2.5$ & 9 \\
\hline
\end{tabular}

${ }^{a}$ Measurements from maximal subthreshold EPSPs.

${ }^{b}$ Significantly different from control; ANOVA, $p<0.05$.

from averages of two to six responses taken at $10 \mathrm{sec}$ intervals; however, traces used in Figures are single responses, not averages, except as noted in Figure 7. Mean data are presented \pm 1 SE. Because synaptic and membrane properties develop rapidly during early postnatal life (Metherate and Aramakis, 1999; present study), a Factorial ANOVA was used for age-matched comparisons between treatment groups. For CNE groups I and II, data were grouped by individual days, whereas for CNE groups III and IV data were pooled within two age ranges, P22-24 and P25-26, because of the small number of cells at each age and the relatively slow rate of change in neuronal properties by P22. Except where noted, additional within-cell and between-group comparisons used $t$ tests for paired or unpaired samples, respectively. Differences were considered significant at $p<0.05$.

Effects of rapid nicotine application to neurons in vitro were determined as described previously (Aramakis and Metherate, 1998). Synaptic potentials were elicited by a single stimulus pulse every $10 \mathrm{sec}$. After several control responses were obtained, pressure-ejected nicotine was paired with the afferent stimulus for several trials, with each pressure pulse beginning $15 \mathrm{msec}$ before the afferent stimulus. For each condition, three to five traces were averaged, and EPSP area was measured. To establish a threshold value for a statistically significant effect, a pre-drug mean EPSP area and SD were calculated for each of five cells. The SD was then expressed as a percentage of the mean, and this value was averaged across cells. The threshold for a significant change in area was established at twice the average SD (95\% confidence interval). This threshold value was 28.8 and $27.4 \%$ for control and CNE neurons, respectively (data from five neurons for each group). Thus, changes in EPSP area of $\sim 30 \%$ or greater were considered significant. To ensure that pressure-ejected nicotine was applied to control and CNE neurons under similar conditions, only neurons from P13 animals were compared, and the nicotine concentration in the pressure pipette was kept constant at $25 \mu \mathrm{M}$.

In situ hybridization and receptor binding. After $\mathrm{CNE}$ or saline treatments, rats were decapitated, and their brains were rapidly removed, frozen, and processed for $\alpha 7$ mRNA levels, $\alpha$-bungarotoxin ( $\alpha$-BTX) binding sites, and nicotine inhibition of $\alpha$-BTX binding, as detailed previously (Broide et al., 1996; Ospina et al., 1998). Briefly, $20 \mu \mathrm{m}$ tissue sections were cryostat cut and mounted onto either gelatin-coated slides (for [ $\left.{ }^{125} \mathrm{I}\right] \alpha$-BTX binding), or slides with an additional coating of poly-L-lysine (for in situ hybridization) and kept at $-20^{\circ} \mathrm{C}$. Sections for [ $\left.{ }^{125} \mathrm{I}\right] \alpha$-BTX binding were stored desiccated at $4^{\circ} \mathrm{C}$ for $2 \mathrm{hr}$ and then at $-20^{\circ} \mathrm{C}$ until use. Sections for in situ hybridization were post-fixed with $4 \%$ paraformaldehyde in $0.1 \mathrm{M} \mathrm{PBS,} \mathrm{pH} \mathrm{7.4,} \mathrm{for} 1 \mathrm{hr}$ at $22^{\circ} \mathrm{C}$, then washed in PBS and air-dried.

A $2.1 \mathrm{~kb}$ cDNA encoding the entire rat $\alpha 7$ subunit cloned into pBluescript II SK ${ }^{+}$was obtained from Dr. Jim Boulter (University of California Los Angeles), and ${ }^{35}$ S-labeled uridine triphosphate was used in synthesizing cRNA riboprobes. These probes were further subjected to alkaline hydrolysis using the method of Cox et al. (1984). Tissue sections were incubated for $18 \mathrm{hr}$ at $60^{\circ} \mathrm{C}$ with a hybridization solution $(50 \%$ formamide, $10 \%$ dextran sulfate, $0.02 \%$ Ficoll, $0.02 \%$ polyvinyl pyrolidone, $0.02 \%$ bovine serum albumin, $500 \mu \mathrm{g} / \mathrm{ml}$ tRNA, $10 \mathrm{~mm}$ dithiothreitol, $0.3 \mathrm{M} \mathrm{NaCl}$, $10 \mathrm{~mm}$ Tris, $\mathrm{pH} 8$, and $1 \mathrm{~mm}$ EDTA, $\mathrm{pH}$ 8) containing labeled cRNA probes in the antisense orientation. Sections were then incubated with RNase A $(20 \mu \mathrm{g} / \mathrm{ml})$ for $30 \mathrm{~min}$ at $37^{\circ} \mathrm{C}$, followed by washes of decreasing salinity $\left(2-0.5 \times \mathrm{SSC}\right.$ buffer) at $22^{\circ} \mathrm{C}$, and a $30 \mathrm{~min}$ wash in $0.1 \times \mathrm{SSC}$ at $70^{\circ} \mathrm{C}$. Tissue sections were dehydrated, dried, and apposed to $\beta$-max film for $3 \mathrm{~d}$ at $4^{\circ} \mathrm{C}$

Tissue sections for $\left.{ }^{125} \mathrm{I}\right] \alpha$-BTX binding were processed using a modification of the method described by Fuchs (1989). Sections were preincubated in a solution containing $120 \mathrm{~mm} \mathrm{NaCl}$ and $50 \mathrm{~mm}$ Tris- $\mathrm{HCl}, \mathrm{pH} 7.4$, for $15 \mathrm{~min}$ at $22^{\circ} \mathrm{C}$. Slides were then incubated at $22^{\circ} \mathrm{C}$ for $2 \mathrm{hr}$ in the same buffer containing $5 \mathrm{~nm}\left[{ }^{125} \mathrm{I}\right] \alpha$-BTX (specific activity $>200 \mathrm{Ci} / \mathrm{mmol}$ ) in the absence or presence of $\alpha$-cobratoxin $(1 \mathrm{mM})$. For competition experiments, tissues were incubated as above, or with 4 or $40 \mu \mathrm{M}$ nicotine. After incubation, slides were washed two times for $10 \mathrm{~min}$ each in Tris buffer at $4^{\circ} \mathrm{C}$ followed by two dips in distilled water, then air-dried. Labeled sections were exposed to radiation-sensitive Hyperfilm, along with ${ }^{14} \mathrm{C}$ standards, for $48 \mathrm{hr}$ at room temperature. After film development, tissue sections were stained with cresyl violet for anatomical analysis.

Autoradiograms were quantified with a computer-based image analysis system (MCID, Imaging Research, St. Catherine, Ontario, Canada) using calibrated standards of reference. A calibration curve of optical density against radioligand concentration (disintegrations per minute per milligrams of tissue for in situ hybridization and femtomols per milligrams of tissue for binding films) was constructed using $\left[{ }^{14} \mathrm{C}\right]$ brain paste standards of known radioactivity. For binding, the curve was calibrated for reading $\left[{ }^{125} \mathrm{I}\right]$ emissions, as described by Miller and Zahniser (1987). Optical densities in the discrete regions of the autoradiogram were measured, and values of radioactivity were calculated by interpolation from the calibration curve. The measurements for specific hybridization were calculated by subtracting values of radioactivity in sections hybridized with sense probe from those hybridized with antisense. The measurements for specific $\alpha$-BTX binding were obtained by subtracting values of nonspecific binding in the presence of cobratoxin from the values of total binding. Nissl-stained slides were used to verify the localization of $\alpha 7$ mRNA and binding sites in the brain. Cortical layers were identified by examination of the pattern and distribution of Nissl-stained cells. A transparency with the outline of each cortical layer was constructed from the Nissl-stained section and used as a template to guide the analysis of the respective autoradiogram.

\section{RESULTS}

Effects of CNE on electrophysiological measures of auditory cortex development were determined using slices from nicotine-injected, saline-injected, and untreated rat pups. Data were obtained from 190 pyramidal neurons in layers II-IV of slices from 68 pups ranging in age from $\mathrm{P} 8$ to $\mathrm{P} 26$. Of these, 45 neurons were from animals that had been injected with nicotine, and 145 neurons were from saline-injected or untreated pups. Synaptic and intrinsic properties from saline-injected pups did not differ from age-matched untreated pups $(p>0.10)$; these data were therefore combined and are referred to as controls. An additional 16 animals injected with nicotine or saline were used for receptor binding and in situ hybridization studies. 


\section{A. i. Control}

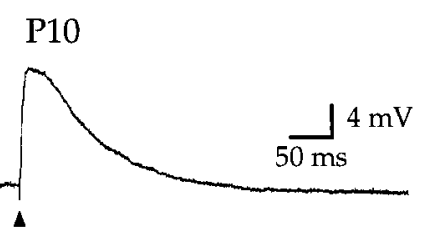

\section{ii. CNE Group I Injections P1 $\rightarrow$ P8-9}
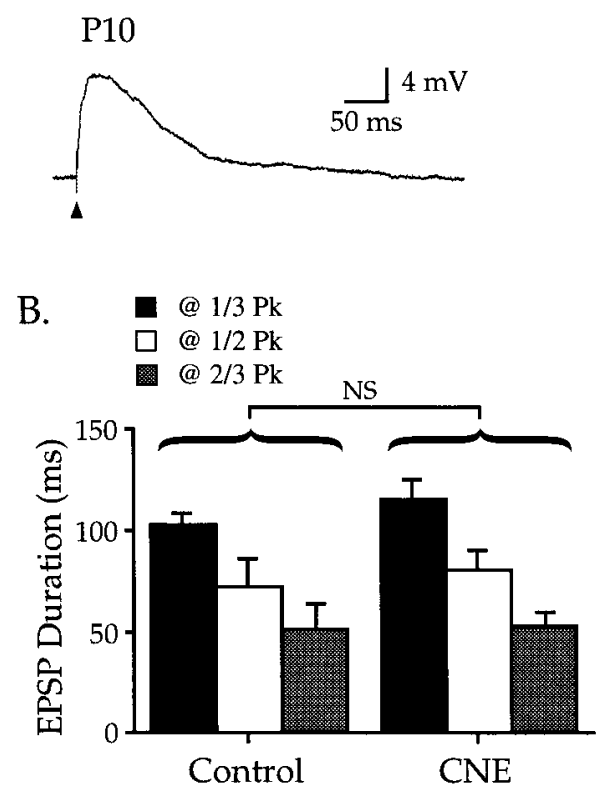

Figure 2. CNE group I: nicotine treatment for approximately the first postnatal week does not affect glutamate EPSPs. $A i$, Representative EPSP in a control P10 neuron; $V_{\mathrm{m}}-66 \mathrm{mV}$. Aii, Nicotine injections from P1-9 resulted in an EPSP that was similar to controls; P10 neuron, $V-61 \mathrm{mV}$. $B, C N E$ group I EPSP durations (measured at $1 / 3,1 / 2$, and $2 / 3 \stackrel{m}{P} k$ ) did not differ from age-matched controls (Table $1 ; p>0.10$ ).

\section{Postnatal development of EPSPs in auditory cortex}

To illustrate synaptic changes during normal postnatal development, data on maximal subthreshold EPSPs were grouped into four age ranges: P8-12, P13-16, P20-22, and P24-26. At the youngest ages, EPSPs were of relatively small amplitude, long duration (measured at one-third, one-half, and two-thirds peak amplitude), and long latency to peak, and required higher stimulus intensities to be elicited (Fig. 1, Table 1). EPSPs from the oldest age range had the largest amplitude, shortest duration, and shortest latency to peak, and required the lowest stimulus intensities. A continuum in these parameters was observed over intermediate ages. [Distances from the stimulating electrode to the recorded neuron averaged $72 \pm 2 \mu \mathrm{m}$ and did not differ between age groups $(p>0.05)]$ These data on postnatal development of synaptic properties served as age-matched controls for the effects of CNE.

\section{Effects of CNE on synaptic development}

As described above (Materials and Methods), four groups of rat pups were exposed chronically to nicotine during different phases of the postnatal nAChR upregulation (CNE groups I-IV). A qualitative assessment of the behavioral effects of nicotine treatments indicated that within $\sim 30 \mathrm{sec}$ of the subcutaneous nicotine injection ( 1 or $2 \mathrm{mg} / \mathrm{kg}$; 0.35 or $0.7 \mathrm{mg} / \mathrm{kg}$ free base), young animals $(<\mathrm{P} 10)$ displayed increased resting tremor and performed "swimming" movements. In older pups, nicotine produced increased locomotion, often resulting in circling movements. Such behavior persisted for up to $15 \mathrm{~min}$, after which time nicotine-injected animals could not be distinguished behaviorally from controls.

\section{CNE group I: CNE from P1 to P8-9 does not affect synaptic development}

Neurons from pups injected with $2 \mathrm{mg} / \mathrm{kg}$ nicotine from P1 to P8-9 had maximal subthreshold EPSPs similar to those from agematched controls (Fig. 2, Table 1). Nicotine-treated animals had similar EPSP peak amplitudes, peak latencies, and durations as control EPSPs and were elicited by stimuli of similar intensity (Table 1) [distances from the stimulating electrode to the recorded neuron did not differ between any CNE group (CNE I-IV) and its control group; $p>0.05$ ]. Thus CNE for $8-9 \mathrm{~d}$, including the entire first postnatal week, did not affect the measurements of synaptic development used in this study.

\section{CNE group II: CNE from P8 to P11-14 disrupts synaptic development}

Nicotine injections ( 1 or $2 \mathrm{mg} / \mathrm{kg}$ ) for $4-7 \mathrm{~d}$ from $\mathrm{P} 8$ through P11-14 dramatically altered EPSPs in two ways (Fig. 3, Table 1). First, EPSPs from nicotine-treated animals had longer durations, measured at one-third, one-half, or two-thirds peak amplitude (Fig. $3 A, C)$. Second, multiple, discrete fluctuations resembling miniature EPSPs appeared prominently on the descending phase of EPSPs (Fig. 3Aii, asterisks). These miniature events occurred spontaneously, but their frequency increased markedly for tens of milliseconds after an afferent stimulus (Fig. 3Bii shows total number of events for 22 cells; comparison of events $50 \mathrm{msec}$ before and after the afferent stimulus demonstrates a statistically significant increase; paired $t$ test, $p<0.001$ ). Similar miniature events occurred at all stimulus intensities (data not shown). Few if any miniature events occurred in control cells (Fig. 3Bi shows total number of events in 22 control cells; small individual events can be seen in traces from $\mathrm{P} 8$ and $\mathrm{P} 20$ cells in Fig. $1 A$ ), nor did control cells show an increase in miniature frequency after an afferent stimulus $(p>0.3)$. Nicotine doses of 1 and $2 \mathrm{mg} / \mathrm{kg}$ were both effective in altering EPSP characteristics (Fig. 3A,C) (comparison of EPSP durations shown in Fig. $3 C ; p>0.1)$. Nicotine-treated EPSPs also tended to have smaller amplitudes and longer peak latencies than controls, but these differences were not significant (Table 1). Together, these data indicate that chronic exposure to nicotine for 4-7 d during the second postnatal week dramatically altered EPSP development in auditory cortex.

\section{CNE group III: long-term effects of CNE}

To determine whether the effects of CNE during the second postnatal week were long lasting, rat pups were injected with 2 $\mathrm{mg} / \mathrm{kg}$ nicotine for $9 \mathrm{~d}$ from P8 to P16 and then allowed to survive for an additional 7-10 d before electrophysiological experiments were performed. EPSPs from P23-26 pups in CNE group III were significantly longer than age-matched controls (Fig. 4, Table 1) $(p<0.01)$, but not as long as CNE group II EPSPs (comparison with CNE group II pups treated with $2 \mathrm{mg} / \mathrm{kg}, p<0.05$ ). EPSPs in CNE group III also displayed a small but significant increase in presumed miniature events within the first $20 \mathrm{msec}$ after the stimulus $(p<0.05)$ (e.g., Fig. 6Bi). Group III EPSPs tended to have smaller amplitudes and longer peak latencies than controls, but these differences were not significant (Table 1). These data indicate that nicotine exposure during the second postnatal week can produce effects that last well into the fourth week. However, the normal developmental trends appear to resume after cessation of CNE.

\section{CNE group IV: CNE from P20 to P23-25 does not affect synaptic development}

A final group of animals was injected with $2 \mathrm{mg} / \mathrm{kg}$ nicotine for 4-6 d from P20 to P23-25, and slices were made on the morning after the last injection. In seven of nine neurons, EPSPs were indistinguishable from those of age-matched controls (Fig. 5Ai, Aii, com- 
A. i. Control

Figure 3. CNE group II: nicotine treatment during postnatal week 2 alters EPSPs. $A i$, Representative EPSP from a control P13 neuron; $V_{\mathrm{m}}-73 \mathrm{mV}$. Aii, Nicotine injections ( 1 or $2 \mathrm{mg} / \mathrm{kg}$ ) from P8 through P11-14 produced EPSPs that were larger in duration and magnitude and had multiple peaks on their descending phase (asterisks). Top trace, $V_{\mathrm{m}}-66 \mathrm{mV}$; middle trace, $V_{\mathrm{m}}-66$ $\mathrm{mV}$; bottom trace, $V_{\mathrm{m}}-77 \mathrm{mV}$. $B$, The time of occurrence of miniature fluctuations is plotted for $50 \mathrm{msec}$ before and $260 \mathrm{msec}$ after the stimulus (10 msec bins; comparisons using Fisher's PLSD). Bi, In 22 control neurons (P9-15), the number of events occurring before or $60 \mathrm{msec}$ after the stimulus did not differ $(p>0.10)$. $\mathrm{Bii}$, For $22 \mathrm{CNE}$ group II neurons (1 and $2 \mathrm{mg} / \mathrm{kg}$ doses combined), the number of events within $60 \mathrm{msec}$ after the stimulus was greater than during either the prestimulus period or the same $60 \mathrm{msec}$ poststimulus period in control neurons $(p>0.10)$. $C$, EPSP durations recorded from CNE group II neurons (measured at $1 / 3,1 / 2$, and $2 / 3$ peak; histogram shading as in Fig. 2) were longer than age-matched controls (Table $1 ; p<0.01$ ). The increase in duration was similar for the two nicotine doses $(p>$ $0.10)$.

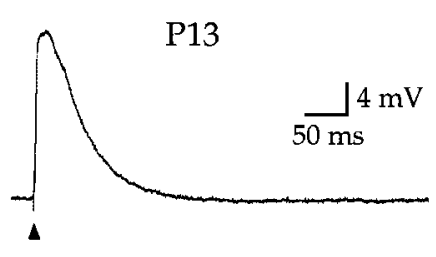

ii. CNE Group II Injections P8 $\rightarrow$ P11-14

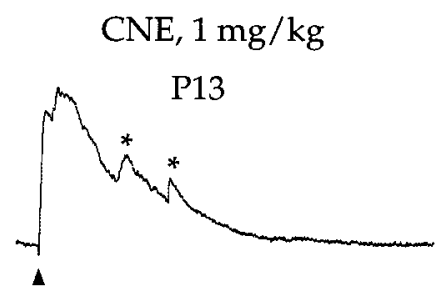

B. i. Control
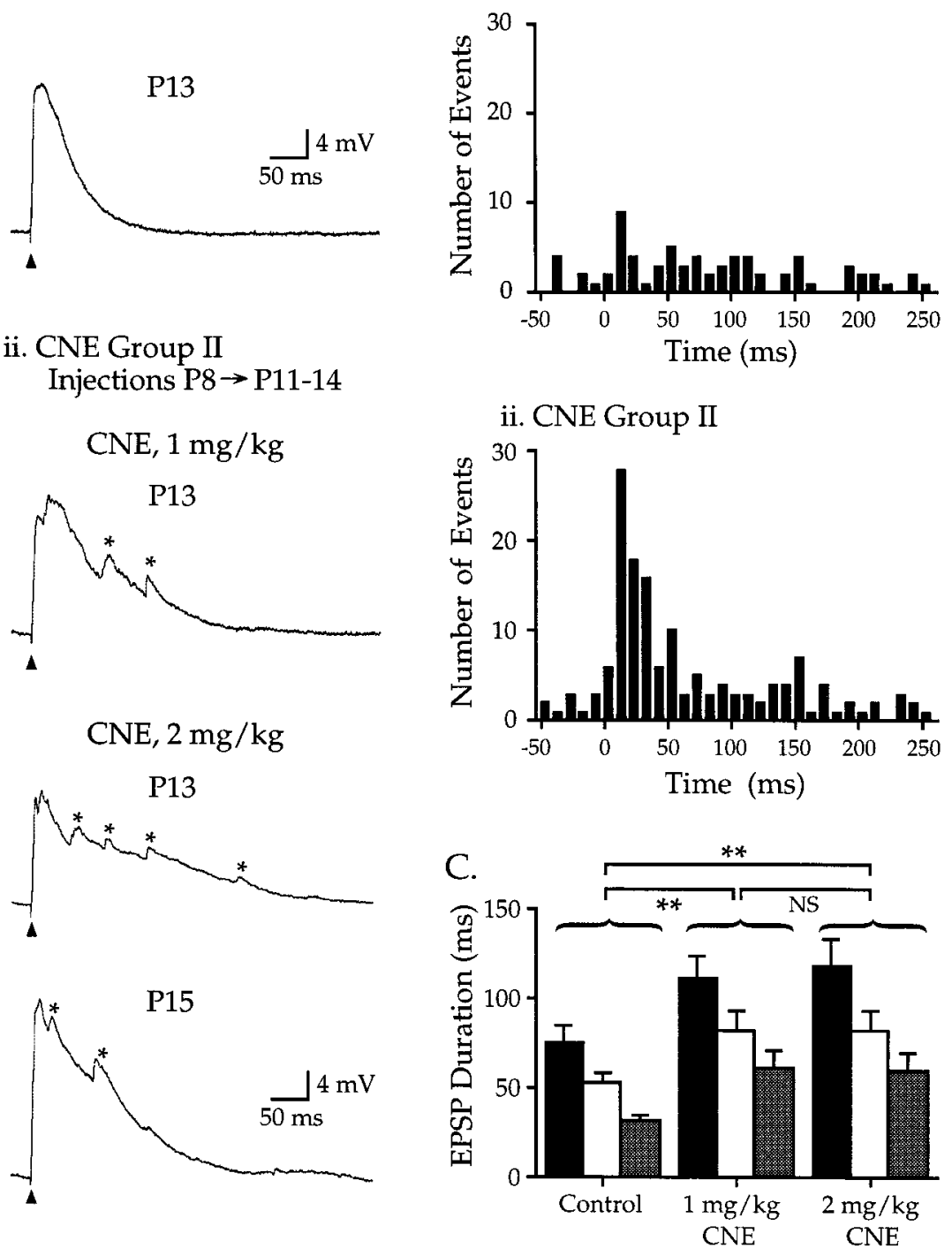

pare P26 neurons). In two neurons, maximal subthreshold EPSPs had longer durations that qualitatively resembled EPSPs in CNE group III (P24 neuron in Fig. 5Aii), although unlike group III, lower intensity stimuli elicited EPSPs resembling controls (Fig. 5Aii, see smaller EPSP for P24 neuron). Nevertheless, group data for all nine neurons in CNE group IV showed that EPSP duration, amplitude, latency to peak, and miniature fluctuations did not differ from control values (Fig. 5B, Table 1) $(p>0.10$; data for miniature fluctuations not shown). Thus, nicotine exposure during the fourth postnatal week did not significantly affect the measurements of synaptic development used in this study.

\section{Effects of CNE on NMDAR EPSPs}

Because our previous study provided evidence that nAChRs selectively regulate EPSPs mediated by NMDARs (Aramakis and Metherate, 1998), we might expect that manipulations of $\mathrm{nAChR}$ function, such as the CNE treatment used here, would selectively affect NMDAR EPSPs. We therefore compared the contribution of NMDARs to EPSPs in neurons from nicotine-exposed and control pups.

\section{CNE group II}

As described above (Fig. 3), nicotine treatment from P8 to P11-14 produced long-duration EPSPs with multiple miniature fluctuations. In neurons from pups treated with $2 \mathrm{mg} / \mathrm{kg}$ nicotine, bath application of the NMDAR antagonist APV $(50 \mu \mathrm{M})$ greatly decreased the magnitude and duration of EPSPs (Fig. 6A) $(n=5$; note that treatment with $1 \mathrm{mg} / \mathrm{kg}$ nicotine produced similar, statistically significant effects in 10 additional neurons, but to facilitate comparisons across CNE groups these data are not shown). Data from APV application allowed comparison of the NMDAR component of the EPSP (obtained by subtracting the EPSP area in APV from the pre-APV area) and the non-NMDAR component (the area in APV) in control and nicotine-treated neurons. As shown in Figure 6Aii, the NMDAR EPSP in CNE group II neurons clearly was enhanced relative to control neurons $(102 \%$ increase, $p<0.01$ ), whereas the non-NMDAR EPSP was unchanged $(p>0.10)$. Importantly, the prominent stimulus-evoked increase in miniature fluctuations seen in CNE group II neurons did not occur in the presence of APV (Fig. 6Aiii). Thus, both the CNE-induced miniature fluctuations and increased EPSP magnitude depended on NMDARs.

\section{CNE group III}

EPSPs recorded 7-10 d after nicotine exposure from P8 to P16 also contained enhanced NMDAR components. APV significantly reduced EPSPs in CNE group III neurons (Fig. $6 B i)(n=5)$, and explicit comparison of the non-NMDAR and NMDAR components of the EPSP area (Fig. 6Bii) demonstrated that CNE more than doubled the NMDAR component (164\% increase, $p<0.05$ ) 
A. i. Control

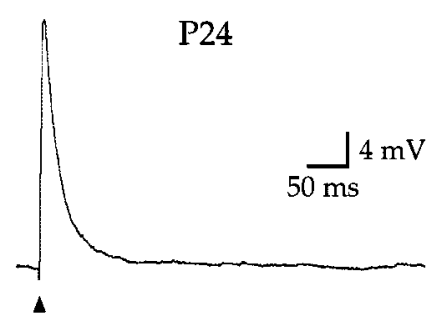

ii. CNE Group III Injections P8 $\rightarrow$ P16
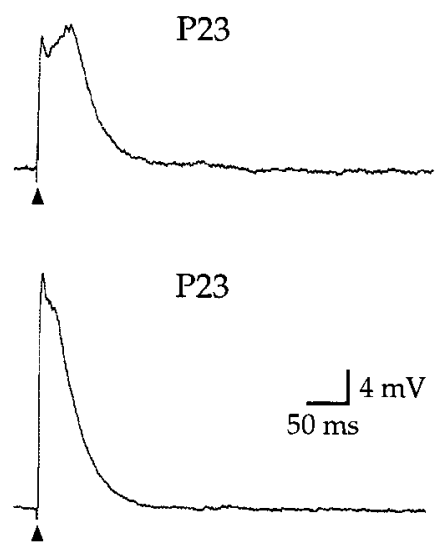

B.

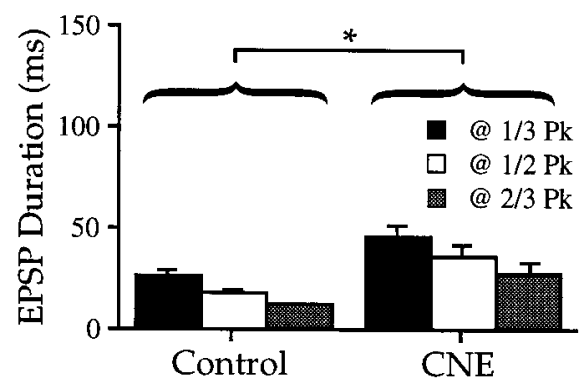

Figure 4. CNE group III: EPSP alterations produced by CNE treatment during week 2 last for at least 1 week. $A i$, Representative EPSP from a control P24 neuron; $V_{\mathrm{m}}-80 \mathrm{mV}$. Aii, EPSPs recorded $7 \mathrm{~d}$ after nicotine injections from P8-16. Top trace, $V_{\mathrm{m}}-68 \mathrm{mV}$; bottom trace, $V_{\mathrm{m}}-79 \mathrm{mV}$. $B$, CNE group III EPSP durations (measured at $1 / 3,1 / 2$, and $2 / 3 P k$ ) were longer than age-matched controls (Table $1 ; p<0.01$ ).

but did not change the non-NMDAR component $(p>0.10)$. These findings are consistent with the data from CNE group II and indicate that CNE during the second postnatal week selectively enhanced the NMDAR component of the EPSP for at least $10 \mathrm{~d}$.

\section{CNE group IV}

APV also reduced the area of EPSPs in neurons from pups exposed to nicotine from P20 to P23-25 (Fig. 6C). However, non-NMDAR and NMDAR components of the EPSP were similar in control and nicotine-treated neurons (Fig. 6Cii) $(p>0.05$; note that although group differences were not significant, the two CNE group IV neurons mentioned above with prominent, wide EPSPs also had prominent APV-sensitive components). On average, therefore, nicotine exposure in the fourth postnatal week did not affect the NMDAR component of the EPSP.

\section{A. i. Control}

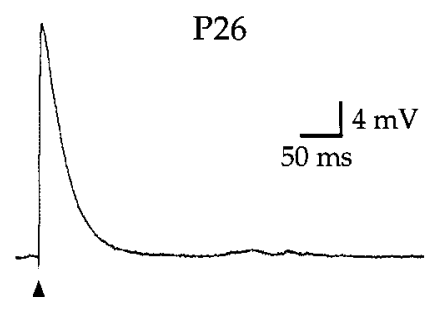

ii. CNE Group IV

Injections P20 $\rightarrow$ P23-25
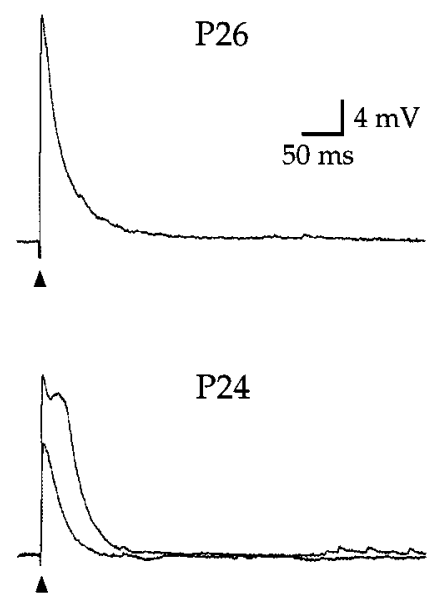

B.

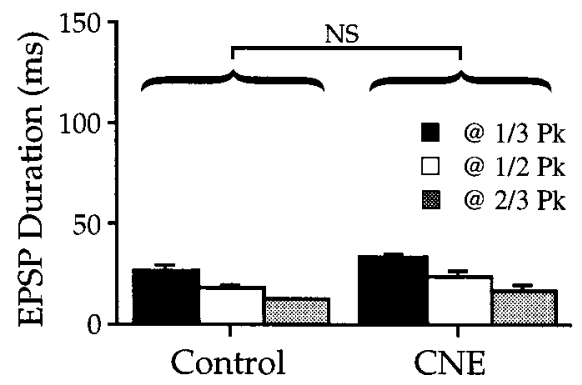

Figure 5. CNE group IV: nicotine treatment during postnatal week 4 does not affect EPSPs. $A i$, Representative EPSP from a control P26 neuron; $V_{\mathrm{m}}$ $-78 \mathrm{mV}$. Aii, CNE from P20 through P23-25 resulted in EPSPs that in general were similar to age-matched controls. Top trace, $V_{\mathrm{m}}-79 \mathrm{mV}$. However, in two of nine neurons, maximal subthreshold EPSPs had enhanced durations, whereas lower intensity stimuli produced control-like durations (bottom traces, $V_{\mathrm{m}}-75 \mathrm{mV}$ ). $B$, CNE group IV EPSP durations did not differ from age-matched controls (Table $1 ; p>0.10$ ).

\section{Effects of acute (pressure-ejected) nicotine on EPSPs after CNE}

Previously we had demonstrated that rapid application of nicotine directly to neurons selectively enhances NMDAR-mediated synaptic transmission in neurons from untreated animals (Aramakis and Metherate, 1998). Because CNE group II neurons in the present study had enhanced EPSPs (Fig. 3) caused by selective enhancement of NMDAR components (Fig. 6), we sought to determine whether these EPSPs could be enhanced further by acute nicotine application (pressure-pulse application from a nicotine-containing micropipette placed adjacent to the apical dendrite of the neuron). Only P13 neurons were used, to examine untreated neurons close to their peak nicotine sensitivity (at $\sim \mathrm{P} 10$ ) (Aramakis and Metherate, 1998), as well as CNE neurons that had 


\section{Ai. CNE Group II}

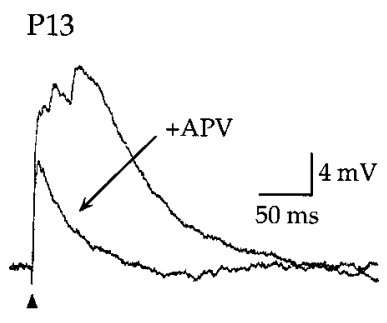

iii. CNE Group II

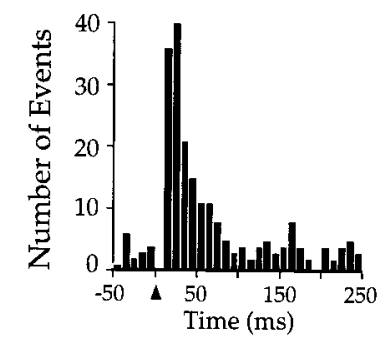

Bi. CNE Group III

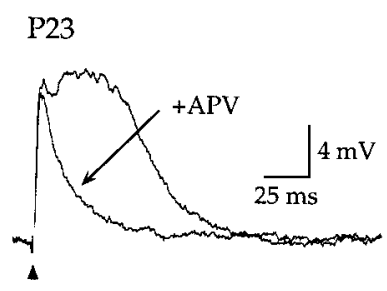

Ci. CNE Group IV

P25

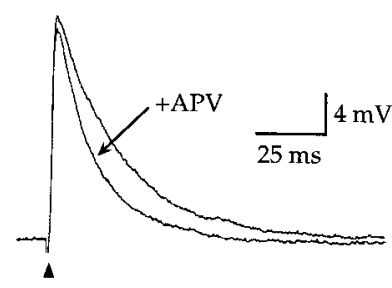

ii.

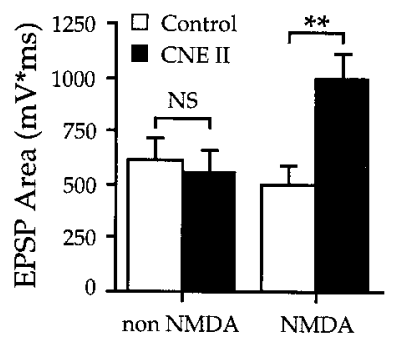

been treated through the peak period (i.e., from P8 to P12). Acute nicotine was applied to 17 untreated neurons and $8 \mathrm{CNE}$ group II neurons (Fig. 7). On average, acute nicotine significantly enhanced the EPSP area in untreated neurons (Fig. $7 B$ ) (from $940 \pm 128$ to $1323 \pm 199 \mathrm{mV} \cdot \mathrm{msec}$; paired $t$ test, $p<0.02$ ) but did not affect CNE neurons $(1171 \pm 170$ to $1259 \pm 176 \mathrm{mV} \cdot \mathrm{msec} ; p>0.2)$. Data from individual neurons (Fig. $7 C$ ) show that acute nicotine significantly enhanced 9 of $17(53 \%)$ untreated neurons by an average of $114 \%$ and 2 of $8(25 \%)$ CNE neurons by an average of $32 \%$ (significant enhancement for individual neurons indicates an increase in EPSP area greater than $\sim 30 \%$; see Materials and Methods for details). Although comparisons between untreated and CNE groups did not reveal statistically significant differences, these data raise the possibility that CNE-induced increases in NMDAR EPSPs (Figs. 3, 6) may limit further enhancement by acute nicotine application (Fig. 7). Future experiments should resolve this issue.

\section{Effects of CNE on the development of intrinsic membrane properties}

Intrinsic membrane properties of layer II-IV pyramidal neurons change dramatically during early postnatal life (Metherate and Aramakis, 1999). Data from control neurons indicate that from P8 to P26 resting potential becomes more negative, input resistance and time constant decrease, spike amplitude increases, spike width decreases, and spike threshold shows no change (Table 2). These data document the normal development of intrinsic membrane properties, against which the effects of CNE can be compared.

CNE during the first postnatal week altered some intrinsic properties, whereas nicotine exposure during the second and fourth weeks had little effect. CNE group I neurons had lower spike thresholds, smaller spike amplitudes, and longer spike widths than age-matched controls, whereas resting potential, input resistance, and time constant were not affected (Table 2). Intrinsic properties for $\mathrm{CNE}$ group II neurons were not affected by nicotine exposure except for a small reduction in spike width, and CNE groups III and IV showed no effects on any measured parameter. Thus, of the membrane properties measured, CNE during the first postnatal week altered those related to spike generation but not passive membrane characteristics. CNE in subsequent weeks exerted little effect on developing membrane properties.

\section{Effects of CNE on $\alpha 7$ nAChRs}

To determine whether nicotine-induced changes in synaptic development resulted from changes in $\alpha 7 \mathrm{nAChRs,} \mathrm{we} \mathrm{determined} \mathrm{levels}$ of $\alpha 7 \mathrm{mRNA}$ and [ $\left.{ }^{125} \mathrm{I}\right] \alpha$-BTX binding (which reflects levels of $\alpha 7$ nAChR protein) (Seguela et al., 1993; Drisdel and Green, 2000) in nicotine- and saline-injected littermates. As with CNE groups II and III, nicotine or saline injections were performed from P8 to $\mathrm{P} 12$, and brains were removed on either P13 or P23. Table 3 shows that nicotine exposure produced a trend toward increased $\alpha 7$ mRNA levels and $\alpha$-BTX binding at P13 and P23; however, only the increase in $\alpha$-BTX binding at P23 reached statistical significance (repeated measures ANOVA, $p<0.001$ ). Thus, the CNEinduced alteration of glutamate EPSPs during postnatal week 2 took place without significant changes in $\alpha 7 \mathrm{nAChR}$ levels.

Despite the apparent lack of change in total $\alpha 7 \mathrm{nAChRs}$ in week 2 (P13 data), it is possible that $\mathrm{CNE}$ altered their functional state. We therefore determined the agonist binding affinity of $\alpha 7$ nAChRs in nicotine- and saline-injected pups. Nicotine inhibition of $\alpha$-BTX binding was no different in the two groups (Table 4), either $1 \mathrm{~d}$ after P8-12 injections (at P13) or $10 \mathrm{~d}$ later (P23), although agonist binding affinity increased over this time (compare P13 and P23 data in Table 4). Thus CNE did not alter the agonist binding affinity of $\alpha 7 \mathrm{nAChR}$ sites, at least not beyond the $\mathrm{CNE}$ period itself.

\section{DISCUSSION}

To investigate whether $\mathrm{nAChR}$ function plays a role in auditory cortex development, we exposed rats chronically to nicotine during 
A.

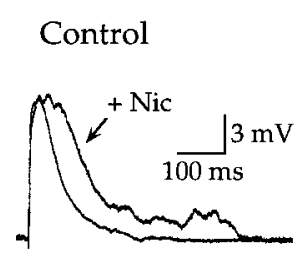

CNE Group II

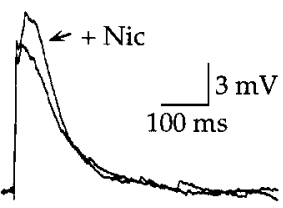

B.

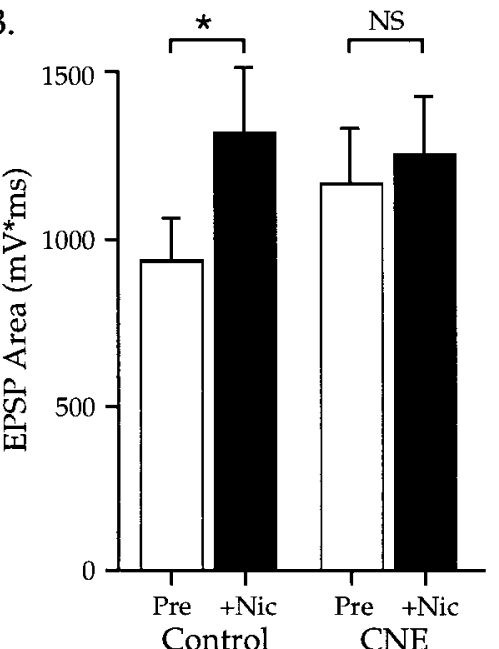

C.

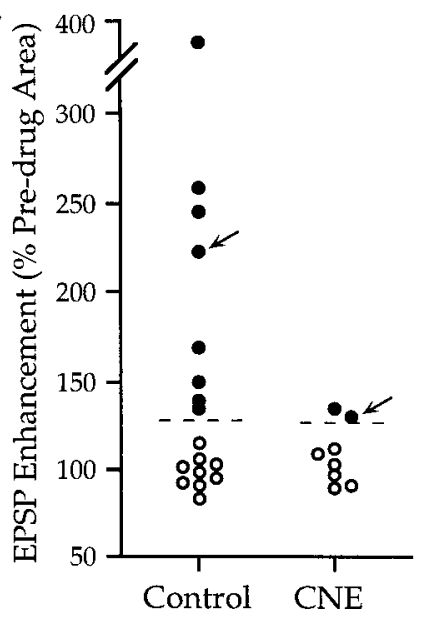

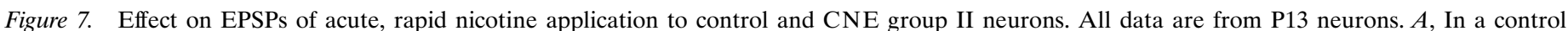

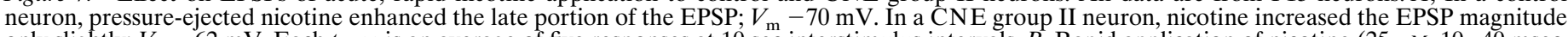

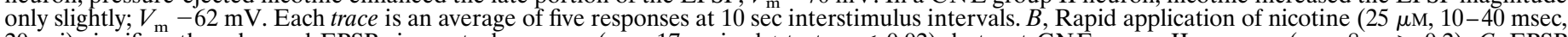

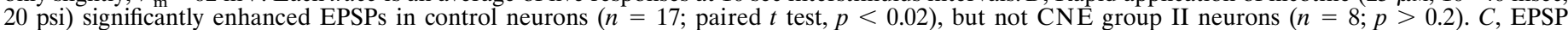

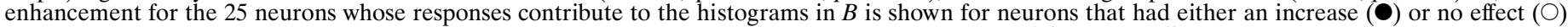

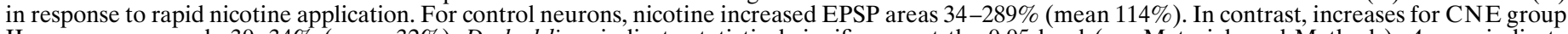

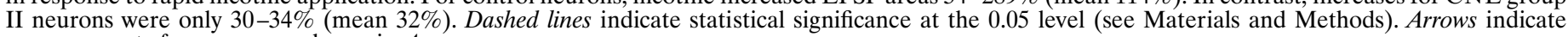
measurements for responses shown in $A$.

Table 2. Intrinsic membrane properties of layers II-IV pyramidal neurons in rat auditory cortex during normal development and after CNE

\begin{tabular}{|c|c|c|c|c|c|c|c|}
\hline Age/condition & RMP (mV) & $\mathrm{Ri}(\mathrm{M} \Omega)$ & $\tau(\mathrm{msec})$ & $\begin{array}{l}\text { Spike threshold } \\
(\mathrm{mV})\end{array}$ & $\begin{array}{l}\text { Spike height } \\
(\mathrm{mV})\end{array}$ & $\begin{array}{l}\text { Spike width } \\
\text { (msec) }\end{array}$ & $n$ \\
\hline \multicolumn{8}{|l|}{ Development } \\
\hline P8-12 & $-64.3 \pm 0.7$ & $282.2 \pm 10.6$ & $22.9 \pm 0.7$ & $-38.7 \pm 0.5$ & $65.6 \pm 1.0$ & $1.2 \pm .03$ & 53 \\
\hline P13-16 & $-68.4 \pm 0.6$ & $195.6 \pm 7.7$ & $18.1 \pm 0.4$ & $-41.1 \pm 0.4$ & $72.8 \pm 0.8$ & $1.1 \pm 0.3$ & 70 \\
\hline $\mathrm{P} 20-22$ & $-72.9 \pm 1.6$ & $72.5 \pm 7.2$ & $11.9 \pm 0.6$ & $-40.9 \pm 0.6$ & $74.3 \pm 1.1$ & $0.74 \pm .03$ & 15 \\
\hline P24-26 & $-76.8 \pm 1.5$ & $49.8 \pm 6.1$ & $8.2 \pm 0.5$ & $-38.9 \pm 1.8$ & $76.4 \pm 2.6$ & $0.68 \pm .03$ & 7 \\
\hline Control & $-64.8 \pm 1.1$ & $305.2 \pm 19.6$ & $21.6 \pm 1.0$ & $-38.2 \pm 0.8$ & $63.8 \pm 1.5$ & $1.1 \pm .04$ & 16 \\
\hline CNE Group I & $-60.8 \pm 1.2$ & $300.0 \pm 24.2$ & $23.3 \pm 2.3$ & $-33.1 \pm 2.4^{a}$ & $50.8 \pm 3.4^{a}$ & $1.5 \pm .12^{a}$ & 5 \\
\hline Control & $-67.5 \pm 0.6$ & $220.5 \pm 7.5$ & $19.6 \pm 0.5$ & $-40.6 \pm 0.4$ & $71.3 \pm 0.9$ & $1.1 \pm .02$ & 71 \\
\hline CNE Group II & $-64.3 \pm 1.3$ & $200.4 \pm 11.0$ & $20.2 \pm 0.9$ & $-40.0 \pm 0.5$ & $67.3 \pm 1.2$ & $0.95 \pm 0.02^{a}$ & 22 \\
\hline Control & $-75.1 \pm 1.9$ & $59.0 \pm 10.4$ & $8.3 \pm 0.3$ & $-39.7 \pm 1.3$ & $75.4 \pm 2.2$ & $0.66 \pm 0.03$ & 10 \\
\hline CNE Group III & $-75.7 \pm 2.1$ & $60.9 \pm 9.0$ & $8.6 \pm 0.8$ & $-42.0 \pm 1.7$ & $75.8 \pm 2.1$ & $0.75 \pm 0.06$ & 7 \\
\hline Control & $-75.1 \pm 1.9$ & $59.0 \pm 10.4$ & $8.3 \pm 0.3$ & $-39.7 \pm 1.3$ & $75.4 \pm 2.2$ & $0.66 \pm 0.03$ & 10 \\
\hline CNE Group IV & $-76.7 \pm 1.2$ & $53.3 \pm 4.3$ & $8.3 \pm 0.3$ & $-43.0 \pm 1.4$ & $79.3 \pm 2.4$ & $0.72 \pm 0.03$ & 9 \\
\hline
\end{tabular}

${ }^{a}$ Significantly different from control; ANOVA, $p<0.05$.

postnatal weeks 1,2 , or 4 , and subsequently examined physiological and anatomical development. CNE during week 1 or 4 had little measurable effect (CNE groups I or IV). However, exposure during week 2 (CNE group II) produced long-duration, multipeaked EPSPs, without changing the levels of $\alpha 7$ nAChRs. The physiological effects were seen even $10 \mathrm{~d}$ after the nicotine treatment (CNE group III), at which time an $\sim 15 \%$ increase in $\alpha 7$ nAChR levels was observed. Pharmacological manipulations indicated that CNE selectively enhanced the NMDAR component of EPSPs. CNE-enhanced EPSPs were only weakly increased further by acute nicotine application, in contrast to the robust enhancement observed in control neurons. These data identify postnatal week 2 as a period during which $\mathrm{CNE}$ can alter synaptic development in rat auditory cortex.

Previously, we have shown in normal animals that rapid activation of $\alpha 7$ nAChRs during postnatal week 2 selectively enhances NMDAR EPSPs (Aramakis and Metherate, 1998). The results implied that presynaptic $\alpha 7 \mathrm{nAChRs}$ regulated glutamate release at synapses that had only NMDARs postsynaptically, i.e., pure-
NMDAR ("silent") synapses. Our present results showing that CNE selectively affects NMDAR EPSPs is consistent with this hypothesis (see below). Although CNE will affect any $\mathrm{nAChR}$, our previous result serves to focus our interpretation and the subsequent discussion on $\alpha 7 \mathrm{nAChRs}$.

\section{nAChR function during and after CNE}

Nicotinic AChRs are ionotropic receptors that gate cation currents, and $\mathrm{nAChRs}$ containing $\alpha 7$ subunits are noteworthy for their high $\mathrm{Ca}^{2+}$ permeability and rapid desensitization (Seguela et al., 1993; Zhang et al., 1994; Castro and Albuquerque, 1995; for review, see Role and Berg, 1996). Presynaptic and postsynaptic $\alpha 7$ nAChRs are found throughout the brain where they can enhance neurotransmitter release and mediate fast synaptic transmission, respectively (for review, see Role and Berg, 1996; Wonnacott, 1997; Jones et al., 1999). During development, $\alpha 7$ nAChRs function in neurite retraction and synapse formation (Pugh and Berg, 1994; Zheng et al., 1994) and regulate glutamate release in sensory cortex (Gil et al., 1997; Aramakis and Metherate, 1998). Other nAChRs may 
Table 3. Density of $\alpha 7$ mRNA and $\left.{ }^{125} \mathrm{I}\right] \alpha-\mathrm{BTX}$ binding sites in auditory cortex of rats treated from P8-12 with saline or nicotine (CNE)

\begin{tabular}{|c|c|c|c|c|}
\hline & \multicolumn{2}{|c|}{$\alpha 7$ mRNA (cpm/mg tissue) } & \multicolumn{2}{|c|}{$\left[{ }^{125} \mathrm{I}\right] \alpha-\mathrm{BTX}(\mathrm{fmol} / \mathrm{mg}$ tissue $)$} \\
\hline & Saline & $\mathrm{CNE}$ & Saline & $\mathrm{CNE}$ \\
\hline \multicolumn{5}{|l|}{ P13 } \\
\hline Layer II/III & $1292 \pm 94$ & $1681 \pm 116$ & $3.2 \pm 0.1$ & $3.3 \pm 0.3$ \\
\hline Layer IV & $1529 \pm 213$ & $1950 \pm 149$ & $4.1 \pm 0.1$ & $4.4 \pm 0.2$ \\
\hline Layer V/VI & $1611 \pm 188$ & $1915 \pm 230$ & $5.0 \pm 0.1$ & $5.3 \pm 0.2$ \\
\hline \multicolumn{5}{|l|}{ P23 } \\
\hline Layer II/III & $1134 \pm 120$ & $1212 \pm 28$ & $2.1 \pm 0.1$ & $2.4 \pm 0.3^{a}$ \\
\hline Layer IV & $1267 \pm 130$ & $1336 \pm 59$ & $2.5 \pm 0.1$ & $2.9 \pm 0.2^{a}$ \\
\hline Layer V/VI & $1291 \pm 117$ & $1361 \pm 53$ & $3.8 \pm 0.1$ & $4.3 \pm 0.2^{a}$ \\
\hline
\end{tabular}

Data are mean \pm SEM for four animals in each group. Saline- versus nicotine-treated groups compared with repeated measures ANOVA.

${ }^{a} p<0.001$.

Table 4. Nicotine inhibition of $\alpha$-BTX binding in auditory cortex of rats treated from P8-12 with saline or nicotine (CNE)

\begin{tabular}{lrllll} 
& \multicolumn{2}{c}{$4 \mu \mathrm{M}$ nicotine } & & & \multicolumn{2}{l}{$40 \mu \mathrm{M}$ nicotine } \\
\cline { 2 - 3 } \cline { 5 - 6 } & \multicolumn{1}{c}{ Saline } & CNE & & Saline & CNE \\
\hline P13 & $8.0 \pm 2.0$ & $11.5 \pm 1.8$ & & $56.9 \pm 8.6$ & $53.9 \pm 3.7$ \\
P23 & $25.9 \pm 2.9$ & $25.9 \pm 1.5$ & & $66.6 \pm 2.6$ & $71.3 \pm 1.7$
\end{tabular}

Data are percentage inhibition (mean \pm SEM) for four animals in each group. Data across layers did not differ significantly and are averaged. No significant differences between $\mathrm{CNE}$ and saline groups.

mediate synaptic transmission in developing sensory cortex (Roerig et al., 1997). Thus CNE can impact cortical development directly via nAChRs.

The CNE protocols used in the present study mimic nicotine blood levels during smoking, which may reach $\sim 0.6 \mu \mathrm{M}$ and remain above baseline levels for hours (Isaac and Rand, 1972; Henningfield et al., 1993; for review, see Benowitz, 1996; Dani and Heinemann, 1996). Exposure to 0.3-0.5 $\mu \mathrm{M}$ nicotine for several minutes will prevent regulation of glutamate EPSPs by $\alpha 7 \mathrm{nAChRs}$ in auditory cortex (Aramakis and Metherate, 1998), presumably by way of receptor desensitization. Thus, our original intent for the present study was to maintain $\mathrm{nAChRs}$ in a desensitized state using the CNE protocol. However, it is not clear what level of desensitization actually occurs and whether it is maintained for the full period between nicotine injections. Low doses of nicotine may not significantly desensitize $\alpha 7$ nAChRs (Fenster et al., 1997), and although chronic exposure can induce prolonged (hours or days) desensitization of nAChRs expressed in oocytes and cell lines (Lukas, 1991; Peng et al., 1994), $\alpha 7$ nAChRs in cultured rat cortical cells can recover within minutes (Kawai and Berg, 1999). Further studies will be needed to characterize nAChR function during the CNE protocol.

Understanding changes in $\mathrm{nAChR}$ function after CNE is complicated by developmental regulation of nAChRs. In mouse, CNE from P10 to P16 decreases the total number of nicotine binding sites in P17 mice; this effect is associated with decreased lowaffinity and increased high-affinity nicotine binding sites (Nordberg et al., 1991). In rat, CNE from P8 to P16 increases $\left[{ }^{3} \mathrm{H}\right]$ nicotine binding in adult cortex, with a shift in agonist binding from a lowto high-affinity state (Miao et al., 1998). However, mRNA levels for several nAChR subunits, including $\alpha 7$, remain unchanged (Miao et al., 1998). These studies conclude that CNE in young rodents can produce long-lasting changes in the numbers and agonist binding affinity of $\mathrm{nAChRs}$, and that postnatal week 2 is a critical period for CNE effects.

In the present study on rat auditory cortex, CNE from $\mathrm{P} 8$ to $\mathrm{P} 12$ did not significantly alter $\alpha 7 \mathrm{nAChR}$ levels ([ $\left.{ }^{125} \mathrm{I}\right] \alpha$-BTX binding sites) at P13, but it increased levels $\sim 15 \%$ after $10 \mathrm{~d}$. CNE also did not affect agonist binding affinity of $\alpha 7 \mathrm{nAChRs,} \mathrm{although} \mathrm{affinity}$ increased during development. Although we focused on $\alpha 7$ nAChRs in rat auditory cortex because of our earlier study (Aramakis and Metherate, 1998), effects of CNE on other nAChR subtypes and in other cortical areas may differ (previous paragraph), given the differential distribution of nAChRs among cortical areas and layers (Fuchs, 1989; Naeff et al., 1992; Broide et al., 1996). However, these data indicate that the striking changes in glutamate-mediated EPSPs produced $1 \mathrm{~d}$ after $\mathrm{CNE}$ are not associated with changes in either the numbers or agonist binding affinity of $\alpha 7 \mathrm{nAChRs}$. Altered EPSPs more likely result from altered $\mathrm{nAChR}$ stimulation during the $\mathrm{CNE}$ protocol than from changes in receptor function per se.

\section{Postnatal week 2 is a "critical period" in rat auditory cortex development}

Several postnatal events are particularly relevant to the present discussion. First, the dramatic upregulation of AChE and $\alpha 7$ $\mathrm{nAChRs}$ in the middle layers of rat auditory cortex begins early in week 1 , peaks during week 2 , and then declines to low (adult) levels by the end of week 3 (Fuchs, 1989; Robertson et al., 1991; Broide et al., 1995). Second, the composition of NMDARs and their contribution to glutamate EPSPs change markedly over the first postnatal weeks, in part driven by sensory experience (Agmon and O'Dowd, 1992; Burgard and Hablitz, 1993; Monyer et al., 1994; Quinlan et al., 1999; for review, see Fox et al., 1999). Some early glutamate synapses are pure NMDAR synapses that are converted, possibly in an experience-dependent process, to mixed AMPA/ NMDAR synapses (Liao et al., 1995; Wu et al., 1996; Isaac et al., 1997). A large body of evidence indicates that cholinergic and glutamatergic functions regulate cortical development and may contribute to postnatal critical periods (Bear and Singer, 1986; Hohmann et al., 1991; Robertson et al., 1998; for review, see Hohmann and Berger-Sweeney, 1998; Fox et al., 1999; Yuste and Sur, 1999). For the auditory system, early week 2 is further distinguished by the onset of hearing and the subsequent, rapid maturation of the cortical auditory evoked potential (Jewett and Romano, 1972; Iwasa and Potsic, 1982). Thus, $\alpha 7 \mathrm{nAChR}$ regulation of NMDAR synapses occurs during a period of intense synaptogenesis and neural circuit formation.

The present study indicates that the second postnatal week may be critical for auditory cortex development, in that CNE produces a dramatic and long-lasting alteration of glutamatergic synaptic transmission. The degree to which this alteration affects acoustic information processing, and hence the designation of week 2 as a critical or sensitive period, remains to be determined. Several mechanisms may underlie the CNE effects. Desensitization of $\alpha 7$ nAChRs would prevent regulation of NMDAR EPSPs (Aramakis and Metherate, 1998), which in turn could prevent or delay the maturation of NMDAR synapses. A delay would produce EPSPs with larger NMDAR components than in age-matched controls, as 
seen in the present study, because NMDAR components normally decrease with age (Agmon and O'Dowd, 1992; Burgard and Hablitz, 1993). Our results suggest a delay in development rather than a permanent halt, because the magnitudes of NMDAR EPSPs resume their decline after cessation of $\mathrm{CNE}$.

An additional finding that is not consistent with a simple delay of maturation, however, is the CNE-induced appearance of stimulusevoked miniature events. These events, which are not prominent in normal development, imply a presynaptic effect of CNE to prolong glutamate release (note also the lack of $\mathrm{CNE}$ effect on postsynaptic membrane properties). Nicotine-induced $\mathrm{Ca}^{2+}$ fluxes in presynaptic terminals (McGehee et al., 1995; Gray et al., 1996) may enhance the slow (asynchronous) component of evoked glutamate release (Goda and Stevens, 1994), leading to longer EPSPs and discrete miniature events. Evidence consistent with this suggestion has been obtained in hippocampal neurons, where repeated stimulation of presynaptic $\alpha 7 \mathrm{nAChRs}$ can produce a long-lasting increase in the frequency of miniature postsynaptic events (Radcliffe and Dani, 1998). Obviously, this scenario is inconsistent with the notion of maintained $\mathrm{nAChR}$ desensitization during CNE. An alternative explanation is that $\mathrm{nAChRs}$ recover between nicotine injections, such that repeated injections lead to repeated, potent stimulation of $\alpha 7 \mathrm{nAChRs}$ and long-lasting enhancement of glutamate release. This could also explain the finding that, after CNE, the effect of acute nicotine (i.e., rapid application directly to neurons) appeared to be reduced. That is, glutamate release already enhanced by CNE might not be enhanced further by acute nicotine application. Future studies must distinguish among these alternatives.

\section{Implications for human auditory development}

If $\alpha 7 \mathrm{nAChR}$-mediated regulation of NMDARs contributes to the maturation of cortical circuits, then CNE could disrupt subsequent auditory function. Supportive evidence exists in studies of human development where the analogous developmental period, including transient cholinergic upregulation in auditory cortex, occurs during the third trimester (Krmpotic-Nemanic et al., 1980, 1983). Children exposed prenatally to nicotine via secondhand smoke show decreased auditory responsiveness (habituation or orientation) and auditory-related cognitive deficits (see introductory remarks). Future studies should determine the developmental role of $\mathrm{nAChRs}$ in shaping auditory function and the effects of perinatal $\mathrm{CNE}$ on auditory dysfunction.

\section{REFERENCES}

Abdulla FA, Bradbury E, Calaminici MR, Lippiello PM, Wonnacott S, Gray JA, Sinden JD (1996) Relationship between up-regulation of nicotine binding sites in rat brain and delayed cognitive enhancement observed after chronic or acute nicotinic receptor stimulation. Psychopharmacology (Berl) 124:323-331.

Agmon A, O'Dowd DK (1992) NMDA receptor-mediated currents are prominent in the thalamocortical synaptic response before maturation of inhibition. J Neurophysiol 68:345-349.

Aramakis VB, Metherate R (1998) Nicotine selectively enhances NMDA receptor-mediated synaptic transmission during postnatal development in sensory neocortex. J Neurosci 18:8485-8495.

Bear MF, Singer W (1986) Modulation of visual cortical plasticity by acetylcholine and noradrenaline. Nature 320:172-176.

Benowitz NL (1996) Pharmacology of nicotine: addiction and therapeutics. Annu Rev Pharmacol Toxicol 36:597-613.

Broide RS, O'Connor LT, Smith MA, Smith JAM, Leslie FM (1995) Developmental expression of $\alpha 7$ neuronal nicotinic receptor messenger RNA in rat sensory cortex and thalamus. Neuroscience 67:83-94.

Broide RS, Robertson RT, Leslie FM (1996) Regulation of alpha-7 nicotinic acetylcholine receptors in the developing rat somatosensory cortex by thalamocortical afferents. J Neurosci 16:2956-2971.

Burgard EC, Hablitz JJ (1993) Developmental changes in NMDA and non-NMDA receptor-mediated synaptic potentials in rat neocortex. J Neurophysiol 69:230-240.

Castro NG, Albuquerque EX (1995) The $\alpha$-bungarotoxin-sensitive hippocampal nicotinic receptor channel has a high calcium permeability. Biophys J 68:516-524.

Cox KH, DeLeon DV, Angerer LM, Angerer RC (1984) Detection of mrnas in sea urchin embryos by in situ hybridization using asymmetric RNA probes. Dev Biol 101:485-502.

Dani JA, Heinemann S (1996) Molecular and cellular aspects of nicotine abuse. Neuron 16:905-908.
Drisdel RC, Green WN (2000) Neuronal $\alpha$-bungarotoxin receptors are $\alpha 7$ subunit homomers. J Neurosci 20:133-139.

Fenster CP, Rains MF, Noerager B, Quick MW, Lester RA (1997) Influence of subunit composition on desensitization of neuronal acetylcholine receptors at low concentrations of nicotine. J Neurosci 17:5747-5759.

Fox K, Henley J, Isaac J (1999) Experience-dependent development of NMDA receptor transmission. Nat Neurosci 2:297-299.

Fried PA, Watkinson B, Siegel LS (1997) Reading and language in 9- to 12-year olds prenatally exposed to cigarettes and marijuana. Neurotoxicol Teratol 19:171-183.

Fuchs JL (1989) $\left[{ }^{125} \mathrm{I}\right] \alpha$-Bungarotoxin binding marks primary sensory areas of developing rat neocortex. Brain Res 501:223-234.

Gil Z, Connors BW, Amitai Y (1997) Differential regulation of neocortical synapses by neuromodulators and activity. Neuron 19:679-686.

Goda Y, Stevens CF (1994) Two components of transmitter release at a central synapse. Proc Natl Acad Sci USA 91:12942-12946.

Gray R, Rajan AS, Radcliffe KA, Yakehiro M, Dani JA (1996) Hippocampal synaptic transmission enhanced by low concentrations of nicotine. Nature 383:713-716.

Henningfield JE, Stapleton JM, Benowitz NL, Grayson RF, London ED (1993) Higher levels of nicotine in arterial than in venous blood after cigarette smoking. Drug Alcohol Depend 33:23-29.

Hohmann CF, Berger-Sweeney J (1998) Cholinergic regulation of cortical development and plasticity. New twists to an old story. Perspect Dev Neurobiol 5:401-425.

Hohmann CF, Kwiterovich KK, Oster-Granite ML, Coyle JT (1991) Newborn basal forebrain lesions disrupt cortical cytodifferentiation as visualized by rapid golgi staining. Cereb Cortex 1:143-157.

Isaac JTR, Crair MC, Nicoll RA, Malenka RC (1997) Silent synapses during development of thalamocortical inputs. Neuron 18:269-280.

Isaac PF, Rand MJ (1972) Cigarette smoking and plasma levels of nicotine. Nature 236:308-310.

Iwasa H, Potsic WP (1982) Maturational change of early, middle, and late components of the auditory evoked responses in rats. Otolaryngol Head Neck Surg 90:95-102.

Jewett DL, Romano MN (1972) Neonatal development of auditory system potentials averaged from the scalp of rat and cat. Brain Res 36:101-115.

Jones S, Sudweeks S, Yakel JL (1999) Nicotinic receptors in the brain: correlating physiology with function. Trends Neurosci 22:555-561.

Kawai H, Berg DK (1999) Long-term nicotinic effects on acetylcholine receptors containing alpha-7 subunits. Abstr Tobacco-Related Disease Research Program Annual Meeting C06.

Kristt DA (1979) Development of neocortical circuitry: histochemical localization of acetylcholinesterase in relation to the cell layers of rat somatosensory cortex. J Comp Neurol 186:1-15.

Krmpotic-Nemanic J, Kostovic I, Kelovic Z, Nemanic D (1980) Development of acetylcholinesterase (AChE) staining in human fetal auditory cortex. Acta Otolaryngol 89:388-392.

Krmpotic-Nemanic J, Kostovic I, Kelovic Z, Nemanic D, Mrzljak L (1983) Development of the human fetal auditory cortex: growth of afferent fibers. Acta Anat 116:69-73.

Liao D, Hessler NA, Malinow R (1995) Activation of postsynaptically silent synapses during pairing-induced LTP in CA1 region of hippocampal slice. Nature 375:400-404.

Lukas RJ (1991) Effects of chronic nicotinic ligand exposure on functional activity of nicotinic acetylcholine receptors expressed by cells of the PC12 rat pheochromocytoma or the TE671/RD human clonal line. J Neurochem 56:1134-1145.

McCartney JS, Fried PA, Watkinson B (1994) Central auditory processing in school-age children prenatally exposed to cigarette smoke. Neurotoxicol Teratol 16:269-276.

McGehee DS, Heath MJ, Gelber S, Devay P, Role LW (1995) Nicotine enhancement of fast excitatory synaptic transmission in CNS by presynaptic receptors. Science 269:1692-1696.

Metherate R, Aramakis VB (1999) Intrinsic electrophysiology of neurons in thalamorecipient layers of developing rat auditory cortex. Dev Brain Res 115:131-144.

Miao H, Liu C, Bishop K, Gong ZH, Nordberg A, Zhang X (1998) Nicotine exposure during a critical period of development leads to persistent changes in nicotinic acetylcholine receptors of adult rat brain. J Neurochem 70:752-762.

Miller JA, Zahniser NR (1987) The use of 14C-labeled tissue paste standards for the calibration of 125I-labeled ligands in quantitative autoradiography. Neurosci Lett 81:345-350.

Monyer H, Burnashev N, Laurie DJ, Sakmann B, Seeburg PH (1994) Developmental and regional expression in the rat brain and functional properties of four NMDA receptors. Neuron 12:529-540.

Murrin LC, Ferrer JR, Zeng WY, Haley NJ (1987) Nicotine administration to rats: methodological considerations. Life Sci 40:1699-1708.

Naeff B, Schlumpf M, Lichtensteiger W (1992) Pre- and postnatal development of high-affinity $[3 \mathrm{H}]$ nicotine binding sites in rat brain regions: an autoradiographic study. Dev Brain Res 68:163-174.

Nash JE (1988) Embryopathic risks of cigarette smoking. Exp Pathol 33:65-73.

Nordberg A, Zhang XA, Fredriksson A, Eriksson P (1991) Neonatal nicotine exposure induces permanent changes in brain nicotinic receptors and behaviour in adult mice. Dev Brain Res 63:201-207. 
Ospina JA, Broide RS, Acevedo D, Robertson RT, Leslie FM (1998) Calcium regulation of agonist binding to $\alpha 7$-type nicotinic acetylcholine receptors in adult and fetal rat hippocampus. J Neurochem 70:1061-1068.

Paxinos G, Watson C (1986) The rat brain in stereotaxic coordinates. New York: Academic.

Peng X, Gerzanich V, Anand R, Whiting PJ, Lindstrom J (1994) Nicotineinduced increase in neuronal nicotinic receptors results from a decrease in the rate of receptor turnover. Mol Pharmacol 46:523-530.

Picone TA, Allen LH, Olsen PN, Ferris ME (1982) Pregnancy outcome in North American women. II. Effects of diet, cigarette smoking, stress, and weight gain on placentas, and on neonatal physical and behavioral characteristics. Am J Clin Nutr 36:1214-1224.

Prusky GT, Arbuckle JM, Cynader MS (1988) Transient concordant distributions of nicotinic receptors and acetylcholinesterase activity in infant rat visual cortex. Brain Res 467:154-159.

Pugh PC, Berg DK (1994) Neuronal acetylcholine receptors that bind $\alpha$-bungarotoxin mediate neurite retraction in a calcium-dependent manner. J Neurosci 14:889-896.

Quinlan EM, Philpot BD, Huganir RL, Bear MF (1999) Rapid, experience-dependent expression of synaptic NMDA receptors in visual cortex in vivo. Nat Neurosci 2:352-357.

Radcliffe KA, Dani JA (1998) Nicotinic stimulation produces multiple forms of increased glutamatergic synaptic transmission. J Neurosci 18:7075-7083.

Robertson RT, Mostamand F, Kageyama GH, Gallardo KA, Yu J (1991) Primary auditory cortex in the rat: transient expression of acetylcholinesterase in developing geniculocortical projections. Dev Brain Res 58:81-95.

Robertson RT, Gallardo KA, Claytor KJ, Ha DH, Ku K-H, Yu BP Lauterborn JC, Wiley RG, Yu J, Gall CM, Leslie FM (1998) Neonatal treatment with 192 IgG-saporin produces long-term forebrain cholinergic deficits and reduces dendritic branching and spine density of neocortical pyramidal neurons. Cereb Cortex 8:142-155.

Roerig B, Nelson DA, Katz LC (1997) Fast synaptic signaling by nicotinic acetylcholine and serotonin $5-\mathrm{HT}_{3}$ receptors in developing visual cortex. J Neurosci 17:8353-8362.

Roger M, Arnault P (1989) Anatomical study of the connections of the primary auditory area in the rat. J Comp Neurol 287:339-356.

Role LW, Berg DK (1996) Nicotinic receptors in the development and modulation of CNS synapses. Neuron 16:1077-1085.

Rowell PP, Li M (1997) Dose-response relationship for nicotine-induced up-regulation of rat brain nicotinic receptors. J Neurochem 68:1982-1989.

Sally SL, Kelly JB (1988) Organization of auditory cortex in the albino rat: sound frequency. J Neurophysiol 59:1627-1638.

Saxton D (1978) The behavior of infants whose mothers smoke in pregnancy. Early Hum Dev 2:363-369.

Seguela P, Wadiche J, Dineley-Miller K, Dani JA, Patrick JW (1993) Molecular cloning, functional properties, and distribution of rat brain $\alpha 7$ : a nicotinic cation channel highly permeable to calcium. J Neurosci 13:596-604.

Sexton M, Fox NL, Hebel JR (1990) Prenatal exposure to tobacco: II. Effects on cognitive functioning at age three. Int J Epidemiol 19:72-77.

Stuart GJ, Dodt H-U, Sakmann B (1993) Patch-clamp recordings from the soma and dendrites of neurons in brain slices using infrared video microscopy. Pflügers Arch 423:511-518.

Wonnacott S (1997) Presynaptic nicotinic ACh receptors. Trends Neurosci 20:92-98.

Wu G-Y, Malinow R, Cline HT (1996) Maturation of a central glutamatergic synapse. Science 274:972-976.

Yuste R, Sur M (1999) Development and plasticity of the cerebral cortex: from molecules to maps. J Neurobiol 41:1-6.

Zhang Z, Vijayaraghavan S, Berg DK (1994) Neuronal acetylcholine receptors that bind alpha-bungarotoxin with high affinity function as ligand-gated ion channels. Neuron 12:167-177.

Zheng JQ, Felder M, Connor JA, Poo M-M (1994) Turning of nerve growth cones induced by neurotransmitters. Nature 368:140-144. 